\title{
MEMAKSIMALKAN METODE USABILITY TESTING DENGAN PENAMBAHAN ATRIBUT COMFORTABILITY SEBAGAI VARIABEL MODERASI
}

\author{
Eny Jumiati ${ }^{1)}$, Wachid Darmawan ${ }^{2),}$ Ari Putra Wibowo,3) \\ STMIK Widya Pratama Pekalongan \\ enyjumiati003@gmail.com,wachid.dw@gmail.com,ariputra.stmikwp@gmail.com
}

\begin{abstract}
Abstrak
Sebuah Website memiliki peran yang cukup penting dalam membantu menyebarkan informasi bagi suatu kelompok atau masyarakat luas. Website yang bermanfaat adalah yang mampu memberikan sesuatu apa yang dibutuhkan oleh pengguna, selain itu mampu memberikan kemanfaatan bagi berlangsungnya proses bisnis yang terjadi dalam organisasi itu sendiri. Semakin banyak yang mengakses website suatu organisasi maka semakin dikenal. Demikian juga dengan STMIK Widya Pratama Pekalongan yang ingin memberikan pelayanan terbaiknya kepada masyarakat secara umum khususnya bagi mahasiswa dan seluruh karyawan dalam memenuhi permintaan informasi yang up to date melalui websitenya. Yang menjadikan pertanyaan adalah apakah website yang dimiliki oleh STMIK Widya pratama itu sebuah produk layanan yang dapat digunakan oleh pengguna serta memenuhi tanggung jawabnya dalam menyajikan antarmuka yang mudah untuk digunakan? Oleh sebab itulah pentingnya pengukuran kualitas website dengan metode usability testing dengan ditambah atribut baru berupa Comfortability bertujuan untuk lebih memaksimalkan ketergunaan(usability) dari interface yang ada dalam website tersebut. Setelah dilakukan pengujian usability dan uji selisih mutlak dapat disimpulkan 74,4\% memiliki hubungan yang kuat antara usability dengan variabel bebas dan 55,4\% usability dipengaruhi secara simultan oleh atribut Learnability, Efficiency, Memorability, Errors, Satifaction dan Comfortability, ini menunjukkan bahwa dengan penambahan atribut Comfortability dapat menguatkan/memaksimalkan usability dari website STMIK Widya Pratama. Untuk penelitian selanjutnya dapat diperbanyak indikator yang digunakan sehingga dapat meningkatkan nilai usabilitynya.
\end{abstract}

\section{Pendahuluan}

Sebuah Website memiliki peran yang cukup penting dalam membantu menyebarkan informasi bagi suatu kelompok atau masyarakat luas. Website yang bermanfaat adalah yang mampu memberikan sesuatu apa yang dibutuhkan oleh pengguna, selain itu mampu memberikan kemanfaatan bagi berlangsungnya proses bisnis yang terjadi dalam organisasi itu sendiri. Semakin banyak yang mengakses website suatu organisasi maka semakin dikenal, hal ini sesuai dengan apa yang disampaikan oleh Direktorat Keamanan Informasi, Direktorat Jendral Aplikasi Informatika dan Kementrian Komunikasi dan Informasi tahun 2011, bahwa website adalah salah satu layanan informasi yang dapat diakses siapapun pengguna internet sehingga harus dapat mengatasi permintaan dari banyaknya pengguna secara lebih baik (Larasati 2020).

Demikian juga dengan STMIK Widya Pratama Pekalongan yang ingin memberikan pelayanan terbaiknya kepada masyarakat secara umum khususnya bagi mahasiswa dan seluruh karyawan dalam memenuhi permintaan informasi yang up to date melalui websitenya sehingga kemanfaatan ataupun ketergunaannya dapat dirasakan secara nyata.

Yang menjadikan pertanyaan adalah apakah website yang dimiliki oleh STMIK Widya pratama itu sebuah produk layanan yang dapat digunakan oleh pengguna serta memenuhi tanggung jawabnya dalam menyajikan antarmuka yang mudah untuk 
digunakan? Oleh sebab itulah pentingnya pengukuran kualitas website dari aspek ketergunaan karena menurut (Hadi, Azzahra, and Fanani 2018) tingkat ketergunaan yang tinggi biasanya akan memiliki pengguna yang banyak serta setia. Menurut (Nielson 2012) ada 5 kualitas komponen atau atribut yang digunakan dalam metode usability yaitu Learnability, Efficiency, Memorability, Errors dan Satifaction. Lima atribut pengujian ini telah dilakukan oleh (MZ 2016),(Aries, Ranius, and Saputri 2017) dan (Huda 2019). Sebenarnya (Nielson 2012) ada banyak atribut penting yang mengacu pada fungsionalitas desain akan tetapi apakah usability dapat tercapai?

Dengan dasar itulah perlunya melakukan pengujian website STMIK Widya Pratama yaitu https://www.stmik-wp.ac.id/ dengan metode usability testing tidak hanya dengan Learnability, Efficiency, Memorability, Errors, Satifaction akan tetapi ditambah dengan atribut baru berupa Comfortability dengan tujuan untuk lebih memaksimalkan ketergunaan dari interface yang ada dalam website tersebut.

\section{Metode Penelitian}

Dalam penelitian ini menggunakan metode evaluasi usabilitas dimana menurut Jacobsen dalam (Dinda 2020) dimana evaluasi usabilitas yang berdasarkan pada pengalaman dari pengguna terhadap suatu system yang berasal dari pertanyaan yang tersusun secara sistematis.

\subsection{Metode Pengumpulan Data}

Pengumpulan data dilakukan dengan cara wawancara, observasi, kuesioner dan studi literature. Wawancara dilakukan kepada staff dan dosen dengan tujuan untuk mengetahui seberapa sering menggunakan website seiring dengan penyelesaian pekerjaannya, serta tujuannya menggunakan website, sedangkan kuesioner dilakukan dengan cara menyebar pertanyaan melalui google form. Untuk melengkapi data maka dilakukan pengamatan terhadap responden pada saat menggunakan website dan penggunaan studi literature.

Teknik Purposive Sampling atau pengambilan sampling berdasarkan pada penilaian subjek kriteria peniliti (Sugiyono 2010) yang digunakan dalam penarikan sampling sedangkan penentuan jumlah responden menggunakan cara pengelompokkan dosen, staff, masyarakat umum dan mahasiswa.
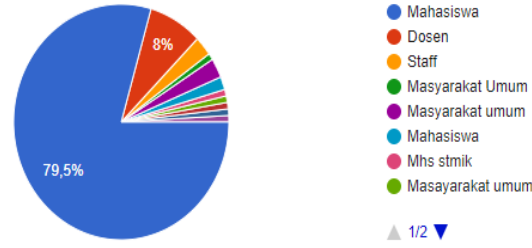

Gambar 1. Jumlah Responden

\subsection{Metode Usability Testing}

Langkah-langkah yang dilakukan dalam usability testing menurut Rubin dan Chisnell dalam (Dinda 2020):

a Perencananaan Pengujian

b Persiapan alat pengujian

c Pencarian dan Penyeleksian Responden

d Persiapan material tes

e Pengujian Usability

f Pengarahan pada responden

g Penganalisaan Data dan observasi

h Pembuatan Laporan dan rekomendasi

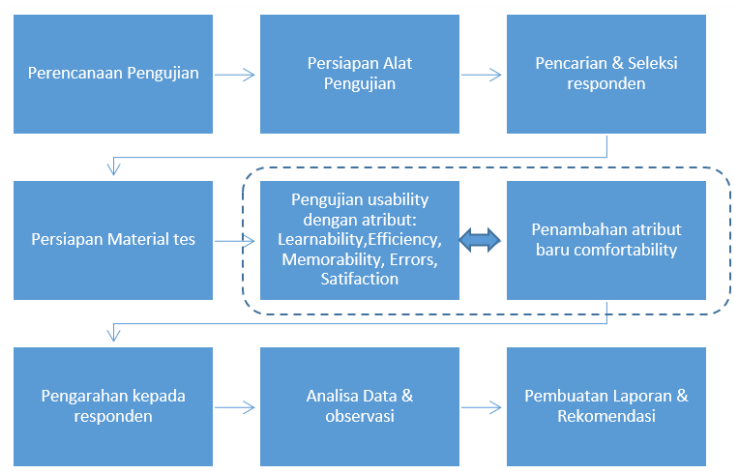

Gambar 2. Metode Usability testing yang diusulkan

\subsection{Eksperimen dan Pengujian}


Dalam eksperimen ada beberapa tahapan yang dilalui yaitu persiapan data pendukung, prosedur pengujian usability, dan proses penyusunan hasil usability testing.

\subsection{Persiapan Data Pendukung}

Data pendukung dilengkapi dengan melakukan persiapan perangkat lunak yang digunakan yaitu hardware, browser Chrome, sebagai sampel penelitian alamat URL https://www.stmik-wp.ac.id/, menyiapkan instrument penelitian berupa komponen Learnability, Efficiency, Memorability, Errors, dan Satifaction (Nielson 2012). Kemudian komponen tersebut ditambah dengan Comfortability sebagai atribut moderasi. Masing-masing instrument dibuat indikatornya, dilanjutkan dengan pembuatan rumusan hipotesa.

Adapun untuk hipotesa yang digunakan menurut(Siswanto 2012):

a Nilai $\mathrm{R}$

HO : Memiliki hubungan yang lemah antara variabel independen dengan variabel dependen (usability)

H1 : Memiliki hubungan yang kuat antara variabel independen dengan

b Nilai R2 dependen (usability)

H0 : Tidak memiliki pengaruh secara signifikan antara variabel independen terhadap variabel dependen (usability)

H1 : Memiliki pengaruh secara signifikan antara variabel independen dengan dependen (usability)

c Nilai signifikansi pada tabel ANOVA

$\mathrm{HO}$ : Dapat memperlemah hubungan variabel independen dengan dependen

H1 : Dapat

Memaksimalkan/memperkuat hubungan antara variabel independen dengan dependen
Tabel 1. Spesifikasi komputer yang digunakan

\begin{tabular}{ll}
\hline Nama Barang & \multicolumn{1}{c}{ Spesifikasi } \\
\hline Processor & Pentium (R) Core i5 2.7 \\
& GHz \\
Memori & DDR3 4 GB \\
Hardisk & 500 GB \\
SIstem Operasi & Windows 10 Ultimate 64- \\
& bit \\
Aplikasi & https://stmik-wp.ac.id/ \\
\hline
\end{tabular}

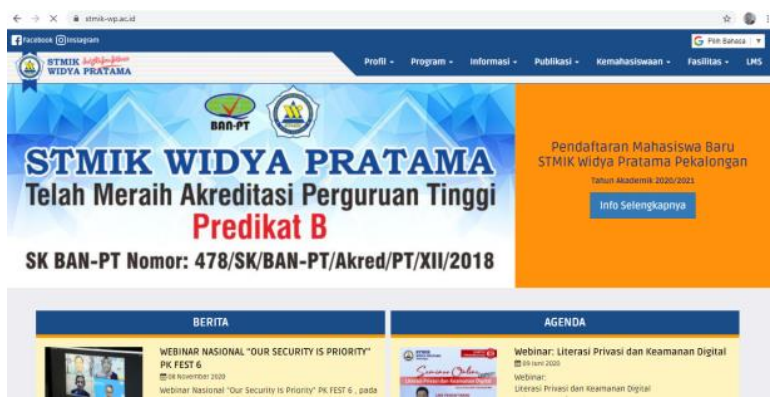

Gambar 3. Halaman Wesite STMIK Widva

2.2. Prosedur Pengujian Usability Testing Pengujian dilakukan dengan menggunakan prosedur sebagai berikut:

a Pengambilan dan penentuan responden Penarikan sampling dilakukan dengan teknik purposive sampling dengan kategori Dosen sebanyak 9, Staff 3, Mahasiswa 96 dan 6 Masyarakat umum

b Mempersiapkan tugas responden dalam pengujian usability

Memberikan tugas bagi responden sebelum melakukan pengujian dengan cara mempersilahkan responden mengakses website STMIK kemudian menjelahi semua fitur yang ada, mengamati apakah timbul error dan tampilan/interface seperti apa termasuk kesesuaian warna dan besarnya huruf yang digunakan.

c Menyebarkan kuesioner sebagai instrument penelitian

Penyebaran kuesioner dilakukan dengan melalui media google form, ini dkarenakan masih dalam situasi pendemi Covid-19. Kuesioner yang disebarkan memiliki 7 variabel/instrument, variabel independent (bebas) terdiri dari: Learnability, Efficiency, Memorability, Errors dan Satifaction, 
sedangkan variabel Dependent (terikat) adalah Usability dan Comfortability sebagai variabel Moderasi, dengan variabel masingmasing mengandung 3 sampai 4 pertanyaan/indikator.

d Melakukan analisis data hasil pengujian Jawaban responden menurut (Sugiyono 2010) perlu untuk diyakinkan dengan skala likert tujuannya adalah untuk pengukuran sikap, pendapat serta anggapan dari seseorang ataupun kelompok orang tentang fenomena sosial dan merupakan skala kontinum bipolar, dimana ujung kiri menunjukkan angka rendah yang menggambarkan negatif sedang ujung kanan mewakili angka jawaban positif. Tabel penilaian dapat dilihat dalam tabel 2. SM= Sangat Mudah, $\quad \mathrm{M}=$ mudah, $\mathrm{CM}=$ cukup mudah, KM=kurang mudah dan KMS=kurang mudah sekali.

Tabel 2. Penilaian angket

\begin{tabular}{|l|l|l|l|l|l|l|}
\hline \multirow{3}{*}{ No } & \multirow{2}{*}{ Pertanyaan } & \multicolumn{5}{|c|}{ Penilaian } \\
\cline { 3 - 7 } & $\begin{array}{l}\text { SM } \\
(5)\end{array}$ & $\begin{array}{l}\text { M } \\
(4)\end{array}$ & $\begin{array}{l}\text { CM } \\
(3)\end{array}$ & $\begin{array}{l}\text { KM } \\
(2)\end{array}$ & $\begin{array}{l}\text { KMS } \\
(1)\end{array}$ \\
\hline & & & & & & \\
\hline
\end{tabular}

\subsection{Proses Penyusunan Hasil Uability Testing}

Hasil penyebaran instrument melalui google form selanjutnya dilakukan konversi menjadi data interval kemudian dilakukan proses perubahan ke data kualitatif skala 5 (Sukarjo 2006). Dari data kualitatif maka tahapan selanjutnya adalah menguji valid dan konsistensi instrument dengan menggunakan uji validitas dan reliabilitas apakah instrument itu konsisten dapat memberikan hasil dengan ukuran yang sama (Priyatno 2013).

Setelah diketahui valid dan konsisten maka langkah berikutnya adalah melakukan uji Moderation Regression Analysis (MRA) yaitu Uji Selisih Mutlak (Siswanto 2012) dengan rumus persamaan: $\mathrm{Y}=\mathrm{a}+\mathrm{b} 1 \mathrm{X} 1+\mathrm{b} 2 \mathrm{X} 2+\mathrm{b} 3[\mathrm{X} 1-\mathrm{X} 2]$, dengan tujuan untuk mengetahui seberapa besarkah atribut comfortability dapat memaksimalkan usability.

\section{Hasil dan Pembahasan}

\subsection{Analisa Data}

Tanggapan yang diperoleh dari penyebaran kuesioner melalui google form sebanyak 112 responden dan selanjutnya dilakukan uji validitas, uji regresi dan moderasi Regression Analysis (MRA), dengan tool SPSS.

\subsubsection{Pengujian Validitas}

Uji validitas yang telah dilakukan terhadap semua indikator pada insrtumen Learnability (X1), Efficiency $(X 2)$, Memorability (X3), Errors(X3), Satifaction(X5),Comfortablity $(C)$,

$\operatorname{Usability}(Y) \quad$ menghasilkan nilai rHitung>rTabel, dimana nilai rTabel sebesar 0,1857 dengan signifikasi 0,05 dari sampel $(\mathrm{N})=112$ yang artinya bahwa semua indicator yang digunakan dalam penelitian ini bernilai valid.

\subsubsection{Pengujian Reliabitas}

Hasil pengujian reliabilitas yang telah dilakukan dan dengan merujuk (Sekaran 1992) dapat diambil kesimpulan bahwa semua indikator yang digunakan bernilai reliabel dapat dilihat dalam tabel 3.1

\begin{tabular}{lcl}
\multicolumn{2}{l}{ Tabel 3.1.Hasil uji reliabilitas } \\
\hline Instrumen & $\begin{array}{l}\text { Jumlah } \\
\text { Indikator }\end{array}$ & $\begin{array}{l}\text { Cronbach's } \\
\text { Alpha }\end{array}$ \\
\hline Learnability & 4 & 0.771 \\
Effiency & 3 & 0,727 \\
Memorability & 4 & 0,778 \\
Errors & 4 & 0,750 \\
Satifaction & 3 & 0,665 \\
Comfortability & 3 & 0,571 \\
Usability & 3 & 0,763 \\
\hline
\end{tabular}

\subsubsection{Uji Selisih Mutlak}

Uji Moderation Regression Analysis yang dilakukan adalah menggunakan uji selisih mutlak bertujuan untuk mencari selisih mutlak variabel moderasi terstandarisasi dengan variabel bebas terstandarisasi(Siswanto 2012). Hasil yang diperoleh dapat dilihat dalam tabel 3.2. dan 3.3 . 
Tabel 3.2. Model Summary

Model Summary

\begin{tabular}{lclrr}
\hline Model & R & R Square & $\begin{array}{c}\text { Adjusted R } \\
\text { Square }\end{array}$ & $\begin{array}{c}\text { Std. Error } \\
\text { of the } \\
\text { Estimate }\end{array}$ \\
\hline 1 & $.744^{\mathrm{a}}$ & .554 & .524 & 1.563 \\
\hline
\end{tabular}

Predictors: (Constant), Moderasi, Zscore(X4),

Zscore(X3), Zscore(X1), Zscore(M), Zscore(X5),

Zscore(X2)

Hasil analisis output menunjukkan:

a Nilai R (koefisien relasi) menghasilkan nilai 0.744 (tolak H0) yang berarti bahwa hubungan variabel independen yang terdiri dari Learnability, Efficiency, Memorability, Errors, Satifaction dan Comfortability dengan dependen Usability lebih kuat.

b Nilai $\mathrm{R}^{2}$ Square (koefisien determinasi) mendpatkan nilai 0.554 yang mengindikasikan bahwa variabel Learnability, Efficiency, Memorability, Errors, Satifaction dan Comfortability mempengaruhi secara simultan atau bersama-sama terhadap variabel Usability sebesar 55,4\% dan sisa yang tidak diteliti dari faktor luar sebesar $44,6 \%$.

Tabel 3.3. Hasil ANOVA

\begin{tabular}{|c|c|c|c|c|c|c|}
\hline Mod & & $\begin{array}{l}\text { Sum of } \\
\text { Squares }\end{array}$ & df & $\begin{array}{l}\text { Mean } \\
\text { Square }\end{array}$ & F & Sig. \\
\hline 1 & $\begin{array}{l}\text { Regression } \\
\text { Residual } \\
\text { Total }\end{array}$ & $\begin{array}{l}314.929 \\
253.990 \\
568.920\end{array}$ & $\begin{array}{r}7 \\
104 \\
111\end{array}$ & $\begin{array}{r}44.990 \\
2.442\end{array}$ & 18.422 & $.000^{6}$ \\
\hline
\end{tabular}

Uji F (berdasarkan output anova) dengan tahapan sebagai berikut:

a Perumusan Hipotesis

HO : Tidak memiliki pengaruh yang signifikan antara variabel independen dengan variabel dependen
H1 : Variabel independen secara simultan berpengaruh terhadap vaiabel dependen secara signifikans.

b Tentukan tingkat signifikansi Dengan dasar signifikansi $\alpha=5 \%$

c Tentukan nilai $\mathrm{F}$ hitung F hitung yang dihasilkan 18,422

d Menentukan nilai $F$ tabel Dengan tingkat keyakinan 95\%, $\alpha=$ $5 \%$, df 1 (jumlah variabel-1) yaitu $(6-1)=5$, df 2 (n-k-1) atau 112-51=106 (n adalah jumlah kasus sedang $\mathrm{k}$ adalah jumlah variabel independen) menghasilkan nilai sebesar 2,30005.

e Pengujian kriteria

$\mathrm{H}_{0}$ diterima bila $\mathrm{F}$ hitung $<\mathrm{F}$ tabel

$\mathrm{H}_{0}$ ditolak jika $\mathrm{F}$ hitung $>\mathrm{F}$ tabel

f Membandingkan $F$ hitung dengan $F$ tabel

$\mathrm{F}$ hitung > F tabel $(18,422>$ 2,30005), maka $\mathrm{H}_{0}$ ditolak

g Menyimpulkan hasil:

Karena nilai $\mathrm{F}$ hitung $>\mathrm{F}$ tabel $(18,422>2,30005)$, maka $\mathrm{H}_{0}$ ditolak, mengartikan bahwa adanya pengaruh yang simultan antara variabel independen dengan dependen secara signifikan. Jadi dapat diambil kesimpulan bahwa atribut Learnability, Efficiency, Memorability, Errors, Satisfaction dan Comfortability secara bersamasama mempengaruhi Usability.

\section{Kesimpulan dan Saran}

\subsection{Simpulan}

Setelah melewati bebarapa metode dan tahapan dalam pengujian Usability Testing dapat ditarik kesimpulan yang menyatakan bahwa:

a Atribut Learnability, Efficiency, Memorability, Errors, Satifaction dan Comfortability memiliki pengaruh yang kuat terhadap Usability dengan nilai koefisien relasi sebesar 74,4\%

$b$ Sedangkan untuk koefisien determinasi sebesar $54,4 \%$ menunjukkan adanya pengaruh 
secara simultan antara atribut Learnability, Efficiency, Memorability, Errors, Satifaction dan Comfortability dengan dependen Usability.

\subsection{Saran}

Untuk pengembangan penelitian selanjutnya adalah masih dimungkinkannya memoderasi atribut dalam pengujian usability testing dengan metode yang berbeda dan penambahan indikatornya sehingga lebih meningkatan usabilitynya.

\section{DAFTAR PUSTAKA}

Aries, Topan Maulana, Ahmad Yani Ranius, and Nurul Adha Oktarini Saputri. 2017. "USABILITY TESTING UNTUK MENGUKUR PENGGUNAAN WEBSITE STIK BINA HUSADA PALEMBANG." Jurnal Teknik Informatika.

Dinda, Meilasari. 2020. "Issn : 2337 - 4349." In ANALISIS USABILITAS PADA SITUS BERITA DENGAN METODE USABILITY TESTING, 359. IENACO.

Hadi, Kevin Ryan, Hanifah Muslimah Azzahra, and Lutfi Fanani. 2018. "Analisis Dan Perbaikan Usability Aplikasi Mobile KAI Access Dengan Metode Usability Testing Dan Use Questionnaire." Jurnal Pengembangan Teknologi Informasi Dan Ilmu Komputer 2 (9): 2743. http://j-ptiik.ub.ac.id.

Huda, Nurul. 2019. "Implementasi Metode Usability Testing Dengan System Usability Scale Dalam Penilaian Website Rs Siloam Palembang." Klik Kumpulan Jurnal Ilmu Komputer 6 (1): 36.

https://doi.org/10.20527/klik.v6i1.177

Larasati, Inggrit. 2020. "Evaluasi Penggunaan Website Universitas Islam Negeri Syarif Hidayatullah Jakarta Dengan." Journal of Computer Science and Information Systems, 4/1 (2020), 68-77 EVALUASI 1: 68-77.

MZ, Yumarlin. 2016. "Evaluasi Penggunaan Website Universitas Janabadra Dengan Menggunakan Metode Usability Testing." Informasi Interaktif 1 (1):
35-44.

Nielson, Jacob. 2012. "Usability 101: Introduction to Usability." 3 Januari 2012, Online. 2012. https://www.nngroup.com/articles/usa bility-101-introduction-to-usability/.

Priyatno, Duwi. 2013. Mandiri Belajar Analisis Data Dengan SPSS. Yogyakarta: Mediakom.

Sekaran, Uma. 1992. Research Methods For Business, A Skill Building Approach, 2nd Edition. New York: Jhon Wiley n Sons.

Siswanto, Victorianus Aries. 2012. Strategi Dan Langkah-Langkah Penelitian. Yogyakarta: Graha Ilmu.

Sugiyono. 2010. Statistika Untuk Penelitian. Bandung: Alfabeta.

Sukarjo. 2006. Evaluasi Pembelajaran, Diktat Kuliah Evaluasi Pembelajaran Program Studi Teknologi. Yogyakarta: Tidak diterbitkan PPs UNY. 